\title{
Amor e Discernimento: Experiência e razão no horizonte pneumatológico das lgrejas
}

Ana Maria Tepedino (org.), São Paulo, Paulinas, 2007, 240p.

\section{Introdução}

O livro 'Amor e Discernimento: experiência e razão no horizonte pneumatológico das Igrejas' reúne nove reflexões organizadas pela professora Ana Maria Tepedino após o término de um curso de pós-graduação em Teologia na PUC-Rio.

A obra surge da inquietação dos-as autores-as diante do atual quadro religioso. Se por um lado há forte indiferença e secularismo, de outro há uma forte efervescência de movimentos pentecostais, principalmente no Brasil. $\mathrm{O}$ fato de o grupo reunir pessoas de diferentes denominações religiosas - quatro católicos-as, um luterano, dois batistas e um congregacional - entre leigos-as e pastores gera uma diversidade de 'olhares' que enriquece a perspectiva teológica que se realiza a partir do diálogo ecumênico sem perder a unidade e o foco principal que norteia todos os artigos - o Espírito Santo.

À luz da Teologia, o livro empreende uma trajetória - através dos textos - que se inicia na tradição da Sagrada Escritura e perpassa as tradições das Igrejas. Neste sentido, busca oferecer critérios para o discernimento cristão, bem como uma proposta de esclarecimento/entendimento da relação entre o contexto social, o tempo histórico e a resposta do ser humano na fé.

'Amor e Discernimento' é composto de quatro blocos de textos que apresentam um desenvolvimento histórico-teológico da pneumatologia. Os textos do Frei Carlos Mesters e da professora Ana Maria Tepedino, leiga católica, abrem o primeiro bloco apresentando a fundamentação bíblica para 
a reflexão pneumatológica. O artigo de Mesters - 'Descobrir e discernir o rumo do Espírito. Uma reflexão a partir da Bíblia' - articula quatro níveis para falar sobre o Espírito: a descrição da experiência, o esforço de compreensão, o esforço do discernimento e, por último, a origem e destino do rumo do Espírito. $\mathrm{O}$ artigo da professora Ana Maria traz a reflexão sobre a experiência da comunidade joanina - 'Das trevas da angústia à consolação do amor. Experiência de fé da comunidade joanina inspirada pelo Espírito Santo'. Marcada por fortes conflitos, esta comunidade experimenta o Ágape, amor que é prática efetiva de vida e que a faz encarnar-se cada vez mais no mundo.

No segundo bloco, os artigos trazem à memória o horizonte e a compreensão da Patrística, através do texto de César Augusto Kuzma, leigo católico - Da experiência à razão. A compreensão pneumatológica em Santo Agostinho - e da Idade Média, através da reflexão de M. Bernardino Filho, pastor congregacional - Escatologia e apocalíptica em Joaquim de Fiore. Uma leitura crítica do tertium testamentum.

$\mathrm{O}$ terceiro bloco adentra no horizonte da modernidade. O pastor luterano Antonio Carlos Ribeiro reflete em seu artigo 'O Espírito na eclesiologia protestante', a partir da perspectiva de Lutero, sobre a ação do Espírito na vida das comunidades eclesiais independentes, sem a tutela institucional, e como estas comunidades refletem a resposta da fé no contexto latinoamericano. Complementa este bloco de abordagens protestantes, o texto do pastor batista Alessandro Rodrigues Rocha - 'A dimensão carismáticolibertadora da pneumatologia protestante. Uma perspectiva marginal' - que articula a tensão entre as estruturas eclesiásticas e a ação desestruturadora do Espírito dentro do protestantismo; abordado a partir de 3 movimentos: o anabatismo, especialmente de Thomas Müntzer, o metodismo de John Wesley e o pentecostalismo liderado por Willian Seymour.

No quarto bloco, a reflexão está centrada sobre os elementos e/ou movimentos da contemporaneidade. O Neopentecostalismo, especialmente da Igreja Universal do Reino de Deus (IURD), é tema principal do artigo 'Neopentecostalismo. Lugar paradoxal. Pode o Espírito soprar aí?' do pastor batista Delambre de Oiveira. A teóloga leiga católica Eva Aparecida Rezende de Moraes traz uma reflexão que tem como ponto de partida o Vaticano II e o pensamento de Yves Congar para apontar critérios-sinais do sopro do Espírito nos dias atuais. O texto que finaliza este bloco é do teólogo leigo católico César Azevedo Carneiro - 'Renovação Carismática Católica. Experiência de um movimento pentecostal no seio da Igreja Católica,' que apresenta os aspectos históricos da RCC, os seus objetivos, propostas, linguagem e num segundo momento, faz uma leitura teológica desse movimento. 
Com toda 'experiência e razão', na apresentação de 'Amor e Discernimento', Ana Maria Tepedino explica porque utiliza o-a ou os-as para expressar o masculino e feminino. Segundo a professora, os-as matemáticos-as ensinam que o traço de fração (a/o) indica subordinação entre o numerador e o denominador. Como representante da primeira geração de teólogas latinoamericanas feministas e libertadoras, ela não poderia deixar de atentar para esta nova articulação e adotá-la na escrita teológica.

Sem dúvida, a obra expressa o rigor teológico necessário, presente desde a sua concepção, metodologia e conclusões, para que o diálogo ecumênico seja efetivamente fecundo e produza bons frutos, mas sobretudo, o livro é de fácil assimilação, permitindo aos leitores-as um vasto 'panorama' pneumatológico que vai desde a Bíblia até os tempos atuais.

Ana Maria L. Tepedino

Doutora pela PUC-Rio

Professora do Departamento de Teologia da PUC-Rio 